Article

\title{
Consumer Choices and Motives for Eco-Labeled Products in China: An Empirical Analysis Based on the Choice Experiment
}

\author{
Qing Liu ${ }^{1}$, Zhen Yan ${ }^{1, *}$ and Jiehong Zhou ${ }^{2, *}$ \\ 1 China Academy for Rural Development (CARD), Zhejiang University, Hangzhou 310058, China; \\ 11320056@zju.edu.cn \\ 2 School of Public Affairs, Zhejiang University, Hangzhou 310058, China \\ * Correspondence: yanzhen@zju.edu.cn (Z.Y.); runzhou@zju.edu.cn (J.Z.) \\ Academic Editor: Yongrok Choi \\ Received: 3 January 2017; Accepted: 20 February 2017; Published: 23 February 2017
}

\begin{abstract}
Based on choice experiments conducted via face-to-face interviews with 435 participants in four provincial areas of China (Shanghai, Zhejiang, Jiangsu, and Guangdong), Chinese consumers' preferences and motives for purchasing eco-labeled rice are examined in this study. The heterogeneous effects of each motivating channel are also investigated. The results reveal positive correlations between premiums for eco-labeled rice and consumers' concerns about food safety and the environment, suggesting that health benefits and environmental considerations are the two critical motivations. The willingness to pay for eco-labeled rice does not increase with consumers' knowledge of the different production standards indicated by each eco-label. Individual characteristics that determine each class are further explored through a seemingly irrelevant regression to identify the target group of consumers for policy-makers.
\end{abstract}

Keywords: eco-labeling; eco-environmental concerns; food safety; choice experiment; latent class model

\section{Introduction}

Food consumption is linked to different environmental impacts. Therefore, consumers' food choices represent significant environmental decisions [1-3]. The public is becoming increasingly concerned about the influence of people's daily activities on the natural environment [4,5], leading to a shift in the focus of environmental policy from supply-related pollution control to demand-oriented instruments to achieve more sustainable consumption patterns [6]. The latter instruments depend mainly on informing consumers about the environmental effect of products and calling on consumers to reduce the environmental damage caused by their purchasing choices [7]. In particular, eco-labeling schemes have received increasing attention and have become an effective, high-profile instrument for achieving environmental goals [6]. Due to the need to influence the way in which products are produced, changes in consumer behavior are important, and eco-labeling constitutes a response.

Eco-labeled products are environmentally preferable products with eco-labels compared to other products in the same category [8-10]. Eco-labeling can generate a change toward more eco-friendly consumption patterns by providing consumers with information about the environmental effects of their consumption and can encourage producers to invest in more sustainable agricultural practices [10]. Eco-labels are effective only if they have real effects on consumer's decision-making [9]. Therefore, it is necessary to know what motivates consumers to pay a premium [7]. Organic labels are a typical type of eco-labeling $[9,11]$ that combines private (perceived health) and public (environmental benefits) characteristics [7]. It is questionable whether such premiums are associated with health concerns or 
environmental worries. With regard to organic food in developed countries, some studies have related green consumption to different motives, with environmental attributes playing a dominant role [12,13]. Other studies have concluded that the purchase of such products is primarily for personal health or food safety considerations [5,14-16]. However, the situation is somewhat different in developing countries, such as China. Given the extensive media coverage about food safety issues and non-point source pollution in China, public concern has increased with regard to better-quality and safer food from farm to table, which increases the demand for organic products [17-19]. Most Chinese consumers choose organic products for food safety reasons rather than environmental concerns [17,19-21]. The motivation for eco-labeled purchasing behavior and its influence on the heterogeneity of consumer preferences require further investigation.

Our study provides insights into consumer preferences and motives for eco-labeled purchasing behavior in China by analyzing individual choices of eco-friendly rice. Rice is selected because it is the staple food in the Chinese diet, so consumers are very familiar with it. Green and organic labels are eco-labels in China (Figure 1) with technical standards, such as quality control and non-pollution, and they carry a special logo. The green label, which is unique to China, allows limited use of synthetic chemicals during production. The organic label, in contrast, represents more stringent standards that resemble those in other countries [22]. Consumers' needs for eco-labeled rice can be transformed into preferences for green or organic labels. However, the eco-labeling system is complicated for consumers because it is composed of a set of production standards, a certification system, and a labeling scheme [23]. Consumers need some knowledge of the production standards underlying eco-labels to distinguish eco-labeled products from non-labeled alternatives $[9,24]$. Though some studies have considered consumers' preferences or consumers' willingness to pay for eco-labeled products as well as their determinants [7,9,25-27], limited attention has been paid to how individuals' knowledge of production standards influences their willingness to pay. With regard to the measurement of consumers' knowledge, self-reported perceptions of eco-labeled products are used to measure knowledge $[17,19,20,28]$. We use six objective true/false questions about production standards rather than subjective cognition to measure consumers' actual knowledge.

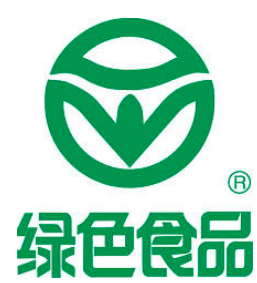

(a)

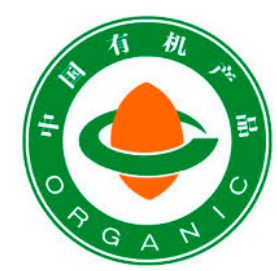

(b)

Figure 1. Picture (a) shows the green label for agri-product; and (b) shows us the organic label in China.

To avoid consumer response bias and numerous uncontrolled decision variables, we introduce a discrete choice experiment in China. Specifically, we analyze the relationship between concern for food safety, concern for the environment, knowledge of production standards and purchase behavior in relation to eco-labeled rice. We first use a mixed logit model to explore heterogeneities in willingness to pay among consumers. We then categorize people based on their motivation, knowledge and socio-economic characteristics to test whether choices of eco-labeled products are driven by environmental concerns in terms of environmental protection using the latent class model. Our findings show that concern for the environment increases the willingness to pay (WTP) for eco-labeled products. To further identify the target group of consumers for policy-makers, we use a seemingly unrelated regression to demonstrate the probability of inclusion in each group with categorical variables. A better understanding of these relationships is essential for designing or improving eco-labeling as an effective demand-oriented instrument to create more sustainable markets through increased green purchases. 


\section{Materials and Methods}

\subsection{Methodology: Choice Modeling}

Choice experiments are widely used in food marketing as well as environmental economics studies to elicit respondents' preferences and WTP for goods [13,29-35]. This study applies choice experiments to investigate consumers' preferences for rice. These experiments asked respondents to select from three possible alternatives two types of rice with different levels of relevant attributes and a "do not buy" option. The "do not buy" option was included because it made the choice scenario more similar to actual markets [33].

Formally, the utility by which an individual $\mathrm{i}$ chooses an alternative $\mathrm{m}$ in choice $\mathrm{t}$ can be specified as:

$$
\mathrm{U}_{\mathrm{imt}}=\mathrm{V}_{\mathrm{imt}}+\varepsilon_{\mathrm{imt}}
$$

where $\mathrm{V}_{\mathrm{imt}}$ is the deterministic component and $\varepsilon_{\mathrm{imt}}$ is a random component of the utility function. The probability that the $i$ th consumer selects type $m$ is given by:

$$
\mathrm{P}(\mathrm{A})=\operatorname{Prob}\left\{\mathrm{V}_{\mathrm{imt}}+\varepsilon_{\mathrm{imt}} \geq \mathrm{V}_{\mathrm{int}}+\varepsilon_{\text {int }} ; \mathrm{m} \neq \mathrm{n}, \forall \mathrm{n} \in \mathrm{C}\right\}
$$

If $\varepsilon_{\text {imt }}$ are independently and identically distributed following a Type I extreme value distribution, then Equation (1) can be converted to a conditional logit model, such as:

$$
\mathrm{L}_{\mathrm{imt}}\left(\beta_{\mathrm{i}}\right)=\frac{\mathrm{e}^{\beta \mathrm{x}_{\mathrm{nit}}}}{\sum_{\mathrm{j}} \mathrm{e}^{\beta \mathrm{x}_{\mathrm{njt}}}}
$$

If there are heterogeneous preferences across respondents, the CL model results become biased. Consequently, the unconditional probability is the integral of rice product over all values of $\beta$ :

$$
P_{\text {nit }}=\int L_{\text {nit }}(\beta) f(\beta \mid \theta) d \beta
$$

\subsection{Economic Model and Empirical Specification}

It is widely accepted that consumers are heterogeneous in their preferences [36-39]. The mixed logit model is recognized as an appropriate approach to capture unobserved heterogeneity, which relaxes the assumption of IIA (independence of irrelevant alternatives) [30,32,36,38]. The latent class model can simultaneously measure the market segmentation and segment-specific parameters to explain the sources of heterogeneity [32]. Consequently, the identified segments exhibit different consumer preferences for attributes associated with attitudinal or socio-demographic characteristics, which have significantly managerial implications [32,40]. We apply the latent class model to examine consumer segmentations based on consumers' knowledge, motives, and individual characteristics.

The probability estimate of this model is as follows:

$$
P(c)=\frac{\exp \left(z_{t}^{\prime} \gamma_{q}\right)}{\sum_{q=1}^{Q} \exp \left(z_{t}^{\prime} \gamma_{q}\right)}
$$

where $\gamma_{\mathrm{Q}}=0, \mathrm{z}_{\mathrm{t}}$ is a series of observed characteristics that affects the classification of respondent into a certain latent class.

After the estimation of the parameters in a latent class model, the WTP values for different attributes can be further calculated using the following formula:

$$
\mathrm{WTP}_{\mathrm{k}}=-\beta_{\mathrm{k}} / \beta_{\mathrm{p}}
$$

where $\beta_{\mathrm{k}}$ is an estimated parameter for the rice-specific attribute and $\beta_{\mathrm{p}}$ is the estimated price coefficient. 


\subsection{Survey Design and Data Description}

A cross-sectional survey was conducted in Zhejiang, Shanghai, Jiangsu, and Guangdong, China, from April to July 2015. The reasons for selecting these four cities were their economic nature, major rice consumption status, and prevalence of food safety incidents and scandals in China. Our questionnaire included the choice experiment, other consumption behavior, motivation, knowledge, and socio-demographic characteristics of the respondents.

We first described rice with a combination of four attributes: brand, eco-labels, geographical origin and price $[13,29,31]$. Attributes, such as taste, were excluded because consumers were not available prior to consumption. Different to some latest studies [41,42], we did not add the sustainable packaging material as an attribute in the experiment due to no eco-labeled packaging logos or such cues in the present Chinese agricultural market. The definitions of the four rice attributes are described in Table 1. The determination of prices included the base price, the middle price, and the highest price, which were derived from national available retail price data. The four rice attributes and their levels were used to build an orthogonal factorial design which is in agreement with other studies $[29,32,37,43-45]$. The "main effects only" designs permit the uncorrelated estimation of all main effects under the assumption that all interactions between attributes are negligible [44-46]. Main effects can account for 70-90 percent of explained variance and are of primary interest in practical applications [30]. We applied the JMP ${ }^{\circledR} 8$ software (SAS Institute, North Carolina) to reduce the original $54\left(3^{3} \times 2\right)$ combinations to 18 sets. The18 choice scenarios about $500 \mathrm{~g}$ packaged rice were then divided into two groups of nine and randomly assigned to each respondent. Table 2 shows one example of a choice scenario. A brief talk that explained to the respondents the importance of reacting as realistically as possible was included to manage the hypothetical nature of the choice experiment [13,32] (Appendix A).

Table 1. Attributes for rice products in choice experiments.

\begin{tabular}{cccc}
\hline Attributes & \multicolumn{3}{c}{ Level Considered } \\
\hline Eco-labels & None & Green label & Organic label \\
Geographical origin & None & Labeled & - \\
Brand & None & Local & National \\
Price $(¥ / 500 \mathrm{~g})$ & $¥ 2.5 / 500 \mathrm{~g}$ & $¥ 4.4 / 500 \mathrm{~g}$ & $¥ 7.5 / 500 \mathrm{~g}$ \\
\hline
\end{tabular}

Table 2. An example of choice sets.

\begin{tabular}{cccc}
\hline & Option A & Option B & Option C \\
\hline Eco-labels & Green & Organic & \\
Geographical origin & Yes & No & Neither \\
Brand & National & None & \\
Price $(¥ / 500 \mathrm{~g})$ & 4.4 & 7.5 & \\
\hline
\end{tabular}

\section{Results and Discussion}

\subsection{Characteristics of the Sample}

A database of 435 participants was obtained for our experiment and investigation. In total, $63.22 \%$ of the participants were female and $36.78 \%$ male (see Table 3 ), which is consistent with the fact that women are the primary purchasers of food in the family in China. Most of the respondents were married. The major age groups were 25-34 years and 35-44 years; these groups accounted for $41.61 \%$ and $26.21 \%$ of the sample, respectively. The household income of most participants $(30.57 \%)$ was more than 14,000 yuan. The average education level was a college degree. Eco-labeled products are purchased mainly by urban consumers in large cities [19], resulting in the higher level of education of the sample. As is often the case with empirical data, less educated people are 
underrepresented $[13,45,47]$. The respondents' motivation was measured by asking about the degree to which they were concerned with agricultural pollution issues and food safety. We measured health motivation with two items, and the environmental motivation with three items. The Cronbach's $\alpha$ values were 0.701 and 0.721 , indicating a high degree of internal consistency of the ratings. The respondents showed more concern for food safety (average score of 3.578) than environmental pollution issues (1.850). The sampled participants had basic knowledge (4.522) about the production standards of eco-labeled rice. Although under or over-representation of the sample is a feature common to other surveys and empirical studies $[13,45,47,48]$, it must be considered when interpreting the results.

Table 3. Socio-demographic characteristics of the sample $(n=435)$.

\begin{tabular}{|c|c|c|c|}
\hline Variables & Description & Mean & SD \\
\hline Gender & $1=$ male $; 0=$ female & 0.368 & 0.482 \\
\hline Marriage & $1=$ married $; 0=$ unmarried & 0.768 & 0.422 \\
\hline Age & $\begin{array}{l}1=18-24 \text { years old } ; 2=25-34 \text { years old } ; 3=35-44 \text { years old } \\
4=45-54 \text { years old } ; 5=55-64 \text { years old; } 6=\text { more than } 65 \text { years old }\end{array}$ & 2.623 & 1.022 \\
\hline Monthly income & $\begin{array}{l}1=\text { less than } 5000 ; 2=5001-8000 \text { yuan; } 3=8001-11,000 \text { yuan; } \\
4=11,001-14,000 \text { yuan; } 5=\text { more than } 14,000 \text { yuan }\end{array}$ & 3.368 & 1.371 \\
\hline Education & $\begin{array}{l}1=\text { middle school or below } ; 2=\text { high school } ; 3=3 \text {-year college; } \\
4=\text { undergraduate } 5=\text { postgraduate }\end{array}$ & 3.731 & 1.001 \\
\hline $\begin{array}{l}\text { Concern for food } \\
\text { safety }\end{array}$ & $\begin{array}{l}\text { How concerned you are with food safety issues }(1-5) \\
\text { How worried are you about rice quality and safety }(1-5)\end{array}$ & 3.578 & 0.864 \\
\hline $\begin{array}{l}\text { Concern for } \\
\text { environment }\end{array}$ & $\begin{array}{l}\text { The large-scale use of chemical pesticides and fertilizers will } \\
\text { pollute the environment (1-5); The severity of current agricultural } \\
\text { pollution caused by planting process (1-5); } \\
\text { The overall situation of China's agricultural pollution (1-5) }\end{array}$ & 1.850 & 0.636 \\
\hline Knowledge & $\begin{array}{l}\text { Based on your understanding, are the following statements } \\
\text { correct (correct = 1; wrong = 0): } \\
\text { (1) Chemical fertilizers can be limited used in green planting; } \\
\text { (2) Chemical pesticides are allowed in green planting; } \\
\text { (3) High toxic and high-persistent pesticides are permitted in } \\
\text { green rice planting; } \\
\text { (4) Organic planting respects environmental protection and } \\
\text { ecological balance; } \\
\text { (5) Chemical pesticides are allowed in organic planting; } \\
\text { (6) Chemical fertilizers are allowed in organic planting; }\end{array}$ & 4.522 & 1.080 \\
\hline
\end{tabular}

\subsection{Estimates of Mixed Logit Model}

Table 4 presents the results of the mixed logit model. As expected, the coefficient of option C ("do not buy") was significantly negative, indicating an increase of utility when choosing one of the presented rice alternatives. This finding suggests that the respondents tend to choose rice with the attributes selected in the experiment rather than the "do not buy" option. Moreover, the standard deviation of each attribute was statistically significant except for the local brand, indicating that consumers are heterogeneous. The price coefficient was negative and statistically significant, showing that an increment of price will reduce a respondent's utility. All of the other coefficients were significantly positive, indicating that consumer utility increases when these traits are included. The two eco-labels had the greatest increment in utility, followed by geographical origin, national brand and local brand. 
Table 4. The results of the mixed logit model.

\begin{tabular}{ccc}
\hline Variables & Mean Coefficient & Derived S.D. Coefficient \\
\hline Price & $-0.333^{* * *}(0.018)$ & NA \\
Option C & $-2.011^{* * *}(0.095)$ & NA \\
Green label & $0.784^{* * *}(0.058)$ & $0.620^{* * *}(0.075)$ \\
Organic label & $0.989^{* * *}(0.060)$ & $0.600^{* * *}(0.080)$ \\
Local brand & $0.333^{* * *}(0.046)$ & $0.088(0.119)$ \\
National brand & $0.371^{* * *}(0.052)$ & $0.487^{* * *}(0.084)$ \\
Geographical origin & $0.771^{* * *}(0.056)$ & $0.950^{* * *}(0.058)$ \\
No. of observations & 11,745 & 11,745 \\
Log-likelihood value & \multicolumn{3}{c}{-2826.794} \\
Chi-square value & \multicolumn{3}{c}{432.88} \\
\hline
\end{tabular}

Notes: Standard errors are in parentheses. ${ }^{* * *}$ denote significance at $1 \%$ levels.

\subsection{Estimates of Latent Class Model}

The maximum likelihood estimates for the latent class model of rice are shown in Table 5. Table 6 presents the willingness to pay for rice attributes in four classes. We used effects coding to measure rice attributes so that the utility for the "do not buy" option was not confounded with the grand mean [13]. The Bayesian Information Criterion (BIC) was employed to fix the number of suitable classes [36,39]. The latent class model (LCM) results showed that the coefficient for the "do not buy" option in each latent class was significantly negative, indicating that participants preferred to choose two types of rice related to a combination of various attributes. The class membership coefficients for the third group were normalized to zero to ensure the remaining coefficients of the model.

Based on the WTP values (attribute/price ratios) of different attributes for each class, the three estimated classes were named as "eco-label preferred", "price sensitive", and "geographical origin oriented" class.

In Class 1, "eco-label preferred", organic labels and green labels have the highest estimation and are significantly positive. Approximately $52.3 \%$ of the respondents belonged to this class. This finding indicates that more than half of the participants preferred eco-labels to improve environmental benefits. Respondents in this class are willing to pay high premiums for eco-labels compared to other groups. They are willing to pay $¥ 6.112 / 500 \mathrm{~g}$ for a green label and $¥ 7.784 / 500 \mathrm{~g}$ for an organic label, followed by a national brand ( $¥ 3.640 / 500 \mathrm{~g}$ ), local brand ( $¥ 2.797 / 500 \mathrm{~g}$ ), and geographical origin ( $¥ 2.510 / 500 \mathrm{~g}$ ), the order of which is consistent with the willingness to pay for the overall sample.

Respondents in Class 2 are "price sensitive". The value of the coefficient for price (1.171) is the highest among all three classes, accounting for $20.9 \%$ of the sample. These participants' willingness to pay for rice attributes is the lowest among the three classes. Nevertheless, they are willing to pay the highest price for eco-labels compared to other attributes, with a premium of $¥ 0.953 / 500 \mathrm{~g}$ for a green label and $¥ 1.061 / 500 \mathrm{~g}$ for an organic label. Despite income constraints, this group still shows a higher preference for eco-labels.

Class 3, "geographical origin oriented", included 117 participants ( $26.8 \%$ of the total sample). The participants in this class prefer geographical origin and pay the highest premium (¥8.268/500 g) relative to the other two classes. The following traits were organic and green labels, with premiums of $¥ 3.151 / 500 \mathrm{~g}$ and $¥ 1.660 / 500 \mathrm{~g}$, respectively. "Geographical origin oriented" participants were also happy to pay a higher premium for eco-labels.

The membership coefficients show that knowledge, motivation and income for Class 1 and Class 2 differ significantly from those of Class 3 . To further examine the impact of each specific variable on the probabilities of respondents falling into each group, we employed a seemingly unrelated regression to investigate the detailed personal characteristics of the three segments. 
Table 5. The results of latent class model.

\begin{tabular}{cccc}
\hline Variables & Class1 & Class2 & Class3 \\
\hline \multirow{3}{*}{ Price } & Utility function coefficients & \\
& $-0.107^{* * *}$ & $-1.171^{* * *}$ & $-0.233^{* * *}$ \\
Green label & $(0.019)$ & $(0.091)$ & $(0.054)$ \\
& $0.653^{* * *}$ & $1.116^{* * *}$ & $0.387^{* * *}$ \\
Organic label & $(0.052)$ & $(0.141)$ & $(0.120)$ \\
& $0.832^{* * *}$ & $1.242^{* * *}$ & $0.735^{* * *}$ \\
Local brand & $(0.058)$ & $(0.167)$ & $(0.119)$ \\
& $0.299^{* * *}$ & 0.191 & $0.868^{* * *}$ \\
National brand & $(0.048)$ & $(0.151)$ & $(0.138)$ \\
& $0.389^{* * *}$ & -0.017 & $0.692^{* * *}$ \\
Geographical origin & $(0.052)$ & $(0.156)$ & $(0.133)$ \\
& $0.268^{* * *}$ & $0.507 * * *$ & $1.928^{* * *}$ \\
Option C & $(0.039)$ & $(0.127)$ & $(0.149)$ \\
& $-2.035^{* * *}$ & $-5.501 * * *$ & -0.195 \\
& $(0.149)$ & $(0.418)$ & $(0.271)$ \\
\hline
\end{tabular}

\begin{tabular}{cccc}
\hline \multirow{4}{*}{ Class membership coefficients } & \\
Knowledge & $-0.283^{* * *}$ & $0.708^{* * *}$ & - \\
& $(0.107)$ & $(0.146)$ & \\
Concern for food safety & -0.056 & $-0.372^{* *}$ & - \\
& $(0.138)$ & $(0.190)$ & \\
Concern for environment & 0.170 & 0.217 & - \\
& $(0.181)$ & $(0.264)$ & \\
Gender & 0.117 & -0.373 & - \\
Marriage & $(0.267)$ & $(0.354)$ & \\
& 0.074 & 0.443 & - \\
Age & $(0.344)$ & $(0.506)$ & \\
& -0.147 & -0.004 & - \\
Education & $(0.134)$ & $(0.200)$ & \\
& 0.181 & 0.272 & - \\
Income & $(0.119)$ & $(0.172)$ & \\
& -0.066 & $-0.270 * *$ & - \\
Constant & $(0.093)$ & $(0.130)$ & \\
& $1.654 * *$ & $-3.087 * *$ & - \\
Latent class share & $(0.712)$ & $(1.274)$ & \\
\hline
\end{tabular}

Notes: Standard errors are in parentheses. ${ }^{* *}{ }^{* * *}$ denote significance at $5 \%$, and $1 \%$ levels, respectively.

Table 6. Implicit price estimates of rice traits.

\begin{tabular}{ccccc}
\hline \multirow{2}{*}{ Traits } & $\begin{array}{c}\text { Mixed Logit } \\
\text { Model }\end{array}$ & \multicolumn{3}{c}{ Latent Class Model } \\
\cline { 3 - 5 } & $2.352^{\mathrm{a}}$ & $6.112^{* * *}$ & Class 2 & Class 3 \\
\hline \multirow{2}{*}{ Green label } & $(1.974,2.730)^{1}$ & $(3.834,8.390)^{\mathrm{b}}$ & $(0.953$ *** & $1.660^{* * * *}$ \\
& 2.967 & $7.784^{* * *}$ & $1.061^{* * *}$ & $3.151^{* * *}$ \\
Organic label & $(2.537,3.398)$ & $(4.766,10.801)$ & $(0.813,1.309)$ & $(1.453,4.849)$ \\
\hline \multirow{2}{*}{ Local brand } & 0.999 & $2.797^{* * *}$ & 0.163 & $3.723^{* * *}$ \\
& $(0.734,1.265)$ & $(1.482,4.113)$ & $(-0.087,0.414)$ & $(2.005,5.441)$ \\
\hline \multirow{2}{*}{ National brand } & 1.114 & $3.640^{* * *}$ & -0.015 & $2.968^{* * *}$ \\
& $(0.785,1.443)$ & $(1.954,5.326)$ & $(-0.276,0.247)$ & $(1.085,4.852)$ \\
\hline \multirow{2}{*}{ Geographical origin } & 2.313 & $2.510^{* * *}$ & $0.433 * * *$ & $8.268^{* * *}$ \\
& $(1.940,2.687)$ & $(1.308,3.711)$ & $(0.233,0.633)$ & $(4.625,11.911)$ \\
\hline
\end{tabular}

\footnotetext{
a Marginal willingness to pay estimates of rice attributes in RMB yuan; ${ }^{b}$ NS: trait not statistically significant;
} $195 \%$ confidence interval level; ${ }^{* * *}$ denote significance at $1 \%$ levels. 


\subsection{Socio-Demographic Profile, Knowledge, and Motivation of the Segments}

In the seemingly unrelated regression model, the probability of the respondents falling into a certain class is an explanatory variable, and individual characteristics are independent variables. The results are presented in Table 7. It shows that safety concerns and environmental concerns have a significantly positive impact on the probability of falling into the eco-label preferred class (Class 1), which has the highest willingness to pay for eco-labels. Consistent with the studies done in other countries [5,14-16], both health motivation and environmental considerations can influence consumer choice of eco-labeled rice, and the health benefits tend to prevail in consumers' motivations. However, our findings are quite different from those earlier investigations on the Chinese consumers [17,19-21], they found that the Chinese consumers would like to choose eco-labeled products for food safety reasons rather than environmental concerns. A possible explanation is that lack of consumer improvement in their environmental awareness due to the recent worsening environment in China.

The third class also has the positive coefficient of concerns for food safety, while the coefficient in the "price sensitive" class is negative. Referring the highest and positive coefficient of food safety concerns in Class 3, respondents in this class pay most attention to information of production areas. Geographical origin becomes a signal of quality improvement as the natural environment endows specific qualities to local products $[29,49,50]$.

Table 7. Individual characteristics for the three consumer segments.

\begin{tabular}{cccc}
\hline Class Membership & Class 1 & Class 2 & Class 3 \\
\hline Concern for food safety & $0.022^{* * *}$ & $-0.050^{* * *}$ & $0.028^{* * *}$ \\
& $(0.005)$ & $(0.004)$ & $(0.005)$ \\
Concern for the & $0.019^{* * *}$ & $0.016^{* * *}$ & $-0.035^{* * *}$ \\
environment & $(0.007)$ & $(0.005)$ & $(0.007)$ \\
& $-0.123^{* * *}$ & $0.117^{* * *}$ & $0.007^{*}$ \\
Knowledge & $(0.004)$ & $(0.003)$ & $(0.004)$ \\
& $0.060^{* * *}$ & $-0.060^{* * *}$ & 0.0003 \\
Gender & $(0.008)$ & $(0.006)$ & $(0.008)$ \\
& $-0.026^{* *}$ & $0.059^{* * *}$ & $-0.033^{* * *}$ \\
Marriage & $(0.011)$ & $(0.009)$ & $(0.011)$ \\
& $-0.034^{* * *}$ & $0.012^{* * *}$ & $0.022^{* * *}$ \\
Age & $(0.005)$ & $(0.004)$ & $(0.005)$ \\
& $0.016^{* * *}$ & $0.024^{* * *}$ & $-0.041^{* * *}$ \\
Education & $(0.005)$ & $(0.004)$ & $(0.004)$ \\
& $0.009^{* * *}$ & $-0.032^{* * *}$ & $0.022^{* * *}$ \\
Income & $(0.003)$ & $(0.002)$ & $(0.003)$ \\
& $0.961^{* * *}$ & $-0.207^{* * *}$ & $0.246^{* * *}$ \\
Constant & $(0.036)$ & $(0.028)$ & $(0.034)$ \\
& &
\end{tabular}

Notes: Standard errors are in parentheses. ${ }^{*}, * *, * * *$ denote significance at $10 \%, 5 \%$, and $1 \%$ levels, respectively.

Our empirical results also show a negative relationship between knowledge and consumers' willingness to pay in Class 1, but strong positive relationship in Class 2 where the participants pay the lowest premium for eco-labels. Purchase incentives may be stimulated when consumers realize that buying eco-labeled products is beneficial to health and the environment without specific knowledge of production standards. Consumers' perceptions of the meaning of an organic label are of a subjective nature and, in many cases, are not based on objective facts [34].

With regard to the socio-demographic background variables, the results indicated that the three latent classes differ significantly $(p<0.01)$ in gender, age, marriage, income, and education. Members of the "eco-label preferred" class (Class 1) are likely to be young, unmarried men, with a relatively higher education and higher income. Participants in the "price sensitive" group tend to be highly educated 
married women with the lowest income level. Consumers who are older unmarried men with the lowest level of education and the highest income are most likely to be members of the "geographical origin oriented" class.

We also compare the results with other studies to identify whether there any differences as our sample has little higher educational level and income than nationwide population in China. Consistent with some higher education data (most are college degree or above), educational level has a positive effect on the willingness to pay for organic products [35,45]. Other studies with overrepresented samples reveal that education level has no significant impact on purchasing behavior [47]. For those less educated sample, the results are equally controversial [51,52]. Since green or organic products always have a higher price, buyers of these products tend to be people with high earnings, which is consistent with previous studies regardless of the sample representation $[19,35,37,47,53]$. In China, older people generally have lower levels of education. However, they are more able to pay the premium for eco-labeled products due to years of economic savings.

\section{Conclusions}

The present study employed mixed logit and latent class models to investigate consumer preferences and motives for eco-labeled rice in China using a choice experiment. This study contributes to the existing literature by combining health motivations and environmental motivations simultaneously in developing countries. To the best of our knowledge, this study is the first attempt to test whether choices of eco-friendly products are driven by environmental concerns in terms of environmental protection. The results suggest that consumers show a positive preference for eco-labeled rice. The greater the concern for food safety and the environment, the more likely consumers are willing to pay a high price for eco-labels. Their possible health benefits and eco-friendly production have important effects on choices of eco-labeled rice products.

Consumers with relatively poor knowledge of the production standards of eco-labels still present positive attitudes toward eco-labeled products because they believe that eco-labeled products are healthier and more environmentally friendly. Consumer preferences for eco-labeled products are somewhat subjective in nature and are not based on adequate understanding, indicating that increasing consumers' favorable impressions of eco-labeled products is of great importance to promoting demand.

Our results confirm that the willingness to pay for eco-labels is heterogeneous among consumers. The results also identify the sources of preference heterogeneity by applying the latent class model. Based on consumers' socio-demographic characteristics, concern for food safety, concern for the environment and knowledge about production standards, they are categorized into three latent classes: the eco-label preferred group, the price-sensitive group, and the geographical origin-oriented group. Consumers in the first group exhibit the highest willingness to pay for both eco-labels. This study identifies the effects of different motives that increase the probability of a consumer being in the eco-label preferred class.

The empirical results provide implications for the design of effective policies to induce consumers to purchase eco-labeled products, which can considerably contribute to a sustainable environment. Governments can make good use of eco-labeling schemes to increase public awareness of the environmental benefits of eco-labeled products, thereby stimulating consumers' environmental motivation. People with certain socio-economic and household characteristics are the target groups for such efforts. The government could produce messages that appeal to emotions about food safety and environmental protection, which may have an impact on behavior by inducing a favorable attitude toward the purchase of eco-friendly products. Since knowledge is critical to establishing correct attitudes toward purchase decisions, it is necessary to enhance the knowledge of the eco-label preferred group. Eco-labeling schemes could be accompanied by information campaigns on the production aspects underlying eco-labels. Given that household consumption of food and beverages in developing countries accounts for more than $90 \%$ of the consumption of these products worldwide, these efforts 
would provide opportunities for the eco-labeled food market and environmental sustainability in developing countries.

Acknowledgments: This research is supported by the National Natural Science Foundation of China (NSFC) Project (Grant No. 71273234 and 71633002), and the Key project of Humanities and Social Science of the Ministry of Education of China (Grant No. 16JJD630007).

Author Contributions: Qing Liu and Jiehong Zhou conceived and designed the choice experiments; Qing Liu and Zhen Yan analyzed the data; Qing Liu and Zhen Yan wrote the paper.

Conflicts of Interest: The authors declare no conflict of interest.

\section{Appendix A}

The following content of the questionnaires only discusses hypothetical scenarios, and the respondents do not need to pay for their choices. Such surveys tend to create situations under which consumers' presumptive purchase behaviors are not consistent with their actual purchase behaviors, most likely because the respondents do not realize how the additional cost would affect their household budgets. In a real store, respondents may think in different ways: money spent on one commodity cannot be used to buy other goods. To avoid this phenomenon, when you answer the following questions about rice purchases, please imagine that you are choosing which type of rice to buy in a supermarket: "If I decided to buy a certain type of rice, then I have to pay".

\section{References}

1. Tobler, C.; Visschers, V.H.; Siegrist, M. Eating green. Consumers' willingness to adopt ecological food consumption behaviors. Appetite 2011, 57, 674-682. [CrossRef] [PubMed]

2. Grunert, S.C. Everybody Seems Concerned about the Environment: But Is This Concern Reflected in (Danish) Consumers' Food Choice? In E-European Advances in Consumer Research; Association for Consumer Research: Duluth, MN, USA, 1993; Volume 1, pp. 428-433.

3. Tukker, A.; Jansen, B. Environmental impacts of products: A detailed review of studies. J. Ind. Ecol. 2006, 10, 159-182. [CrossRef]

4. Mostafa, M.M. Gender differences in Egyptian consumers? Green purchase behaviour: The effects of environmental knowledge, concern and attitude. Int. J. Consum. Stud. 2007, 31, 220-229. [CrossRef]

5. Krystallis, A.; Chryssohoidis, G. Consumers' willingness to pay for organic food: Factors that affect it and variation per organic product type. Br. Food J. 2005, 107, 320-343. [CrossRef]

6. Bleda, M.; Valente, M. Graded eco-labels: A demand-oriented approach to reduce pollution. Technol. Forecast. Soc. Chang. 2009, 76, 512-524. [CrossRef]

7. Bougherara, D.; Combris, P. Eco-labelled food products: What are consumers paying for? Eur. Rev. Agric. Econ. 2009, 36, 321-341. [CrossRef]

8. Loureiro, M.L.; McCluskey, J.J.; Mittelhammer, R.C. Assessing consumer preferences for organic, eco-labeled, and regular apples. J. Agric. Resour. Econ. 2001, 26, 404-416.

9. Daugbjerg, C.; Smed, S.; Andersen, L.M.; Schvartzman, Y. Improving eco-labelling as an environmental policy instrument: Knowledge, trust and organic consumption. J. Environ. Policy Plan. 2014, 16, 559-575. [CrossRef]

10. Galarraga Gallastegui, I. The use of eco-labels: A review of the literature. Eur. Environ. 2002, 12, 316-331. [CrossRef]

11. Sønderskov, K.M.; Daugbjerg, C. The state and consumer confidence in eco-labeling: Organic labeling in Denmark, Sweden, the United Kingdom and the United States. Agric. Hum. Values 2011, 28, 507-517. [CrossRef]

12. Aertsens, J.; Mondelaers, K.; Verbeke, W.; Buysse, J.; Van Huylenbroeck, G. The influence of subjective and objective knowledge on attitude, motivations and consumption of organic food. Br. Food J. 2011, 113, 1353-1378. [CrossRef]

13. Zanoli, R.; Scarpa, R.; Napolitano, F.; Piasentier, E.; Naspetti, S.; Bruschi, V. Organic label as an identifier of environmentally related quality: A consumer choice experiment on beef in Italy. Renew. Agric. Food Syst. 2013, 28, 70-79. [CrossRef] 
14. De Magistris, T.; Gracia, A. The decision to buy organic food products in southern Italy. Br. Food J. 2008, 110, 929-947. [CrossRef]

15. Onyango, B.M.; Hallman, W.K.; Bellows, A.C. Purchasing organic food in US food systems: A study of attitudes and practice. Br. Food J. 2007, 109, 399-411. [CrossRef]

16. Vega-Zamora, M.; Torres-Ruiz, F.J.; Murgado-Armenteros, E.M.; Parras-Rosa, M. Organic as a heuristic cue: What Spanish consumers mean by organic foods. Psychol. Mark. 2014, 31, 349-359. [CrossRef]

17. Yin, S.; Xu, Y.; Chen, M. Consumers purchase decisions and affecting factors on organic food. China Popul. Resour. Environ. 2013, 7, 136-141.

18. Xin-jian, C.; Tao, D.; Gan-jun, Y. Analysis of urban consumers'perception and purchase decision towards organic food. J. Huazhong Agric. Univ. (Soc. Sci. Ed.) 2014, 2, 80-87.

19. Yin, S.; Wu, L.; Du, L.; Chen, M. Consumers' purchase intention of organic food in China. J. Sci. Food Agric. 2010, 90, 1361-1367. [CrossRef] [PubMed]

20. Zhang, H. Empirical study on the green agricultural products' consumer behavior in Guangzhou and its influential factors. J. Northwest A F Univ. (Soc. Sci. Ed.) 2010, 4, 52-56.

21. Jin, M.; Zhao, C. Analysis on consumption intention and consumption behavior of green agricultural products. Chin. Rural Econ. 2008, 24, 44-55.

22. Yu, X.; Gao, Z.; Zeng, Y. Willingness to pay for the "green food" in China. Food Policy 2014, 45, 80-87. [CrossRef]

23. Boström, M.; Klintman, M. Green Labels and Other Eco-Standards: A Definition. In Eco-Standards, Product Labelling and Green Consumerism; Palgrave Macmillan UK: London, UK, 2008; pp. 27-32.

24. Thøgersen, J. Psychological determinants of paying attention to eco-labels in purchase decisions: Model development and multinational validation. J. Consum. Policy 2000, 23, 285-313. [CrossRef]

25. Loureiro, M.L.; McCluskey, J.J.; Mittelhammer, R.C. Will consumers pay a premium for eco-labeled apples? J. Consum. Aff. 2002, 36, 203-219. [CrossRef]

26. Xu, P.; Zeng, Y.; Fong, Q.; Lone, T.; Liu, Y. Chinese consumers' willingness to pay for green- and eco-labeled seafood. Food Control 2012, 28, 74-82. [CrossRef]

27. Moon, W.; Florkowski, W.J.; Brückner, B.; Schonhof, I. Willingness to pay for environmental practices: Implications for eco-labeling. Land Econ. 2002, 78, 88-102. [CrossRef]

28. Martin, B.; Simintiras, A.C. The impact of green product lines on the environment: Does what they know affect how they feel? Mark. Intell. Plan. 1995, 13, 16-23. [CrossRef]

29. Loureiro, M.L.; Umberger, W.J. A choice experiment model for beef: What US consumer responses tell us about relative preferences for food safety, country-of-origin labeling and traceability. Food Policy 2007, 32, 496-514. [CrossRef]

30. Louviere, J.J.; Hensher, D.A.; Swait, J.D. Stated Choice Methods: Analysis and applications; Cambridge University Press: Cambridge, UK, 2000.

31. Ortega, D.L.; Wang, H.H.; Olynk, N.J.; Wu, L.; Bai, J. Chinese consumers' demand for food safety attributes: A push for government and industry regulations. Am. J. Agric. Econ. 2012, 94, 489-495. [CrossRef]

32. Nguyen, T.T.; Haider, W.; Solgaard, H.S.; Ravn-Jonsen, L.; Roth, E. Consumer willingness to pay for quality attributes of fresh seafood: A labeled latent class model. Food Qual. Preference 2015, 41, 225-236. [CrossRef]

33. Van Wezemael, L.; Caputo, V.; Nayga, R.M.; Chryssochoidis, G.; Verbeke, W. European consumer preferences for beef with nutrition and health claims: A multi-country investigation using discrete choice experiments. Food Policy 2014, 44, 167-176. [CrossRef]

34. Janssen, M.; Hamm, U. Product labelling in the market for organic food: Consumer preferences and willingness-to-pay for different organic certification logos. Food Qual. Preference 2012, 25, 9-22. [CrossRef]

35. Aoki, K.; Akai, K.; Ujiie, K. A choice experiment to compare preferences for rice in thailand and Japan: The impact of origin, sustainability, and taste. Food Qual. Preference 2017, 56, 274-284. [CrossRef]

36. Ouma, E.; Abdulai, A.; Drucker, A. Measuring heterogeneous preferences for cattle traits among cattlekeeping households in East Africa. Am. J. Agric. Econ. 2007, 89, 1005-1019. [CrossRef]

37. Ortega, D.L.; Wang, H.H.; Wu, L.; Olynk, N.J. Modeling heterogeneity in consumer preferences for select food safety attributes in China. Food Policy 2011, 36, 318-324. [CrossRef]

38. Hensher, D.A. Greene, W.H. The Mixed Logit model: The state of practice. Transportation 2003, 30, 133-176. [CrossRef] 
39. Boxall, P.C.; Adamowicz, W.L. Understanding heterogeneous preferences in random utility models: A latent class approach. Environ. Resour. Econ. 2002, 23, 421-446. [CrossRef]

40. Wedel, M.; Kamakura, W.; Böckenholt, U. Marketing data, models and decisions. Int. J. Res. Mark. 2000, 17, 203-208. [CrossRef]

41. Magnier, L.; Schoormans, J.; Mugge, R. Judging a product by its cover: Packaging sustainability and perceptions of quality in food products. Food Qual. Preference 2016, 53, 132-142. [CrossRef]

42. Magnier, L.; Schoormans, J. Consumer reactions to sustainable packaging: The interplay of visual appearance, verbal claim and environmental concern. J. Environ. Psychol. 2015, 44, 53-62. [CrossRef]

43. Klaiman, K.; Ortega, D.L.; Garnache, C. Perceived barriers to food packaging recycling: Evidence from a choice experiment of US consumers. Food Control 2017, 73, 291-299. [CrossRef]

44. Street, D.J.; Burgess, L.; Louviere, J.J. Quick and easy choice sets: Constructing optimal and nearly optimal stated choice experiments. Int. J. Res. Mark. 2005, 22, 459-470. [CrossRef]

45. Rousseau, S.; Vranken, L. Green market expansion by reducing information asymmetries: Evidence for labeled organic food products. Food Policy 2013, 40, 31-43. [CrossRef]

46. Mangham, L.J.; Hanson, K.; McPake, B. How to do (or not to do) ... Designing a discrete choice experiment for application in a low-income country. Health Policy Plan. 2009, 24, 151-158. [CrossRef] [PubMed]

47. Gracia, A.; de Magistris, T. The demand for organic foods in the south of italy: A discrete choice model. Food Policy 2008, 33, 386-396. [CrossRef]

48. Denver, S.; Jensen, J.D. Consumer preferences for organically and locally produced apples. Food Qual. Preference 2014, 31, 129-134. [CrossRef]

49. Van Ittersum, K.; Candel, M.J.J.M.; Meulenberg, M.T.G. The influence of the image of a product's region of origin on product evaluation. J. Bus. Res. 2003, 56, 215-226. [CrossRef]

50. Roosen, J.; Lusk, J.L.; Fox, J.A. Consumer demand for and attitudes toward alternative beef labeling strategies in France, Germany, and the UK. Agribusiness 2003, 19, 77-90. [CrossRef]

51. Yin, S.; Chen, M.; Xu, Y.; Chen, Y. Chinese consumers' willingness-to-pay for safety label on tomato: Evidence from choice experiments. China Agric. Econ. Rev. 2017, 9, 141-155. [CrossRef]

52. Zhao, H.-H.; Gao, Q.; Wu, Y.-P.; Wang, Y.; Zhu, X.-D. What affects green consumer behavior in China? A case study from Qingdao. J. Clean. Prod. 2014, 63, 143-151. [CrossRef]

53. Bellows Anne, C.; Onyango, B.; Diamond, A.; Hallman William, K. Understanding consumer interest in organics: Production values vs. Purchasing behavior. J. Agric. Food Ind. Organ. 2008, 6, 1169. [CrossRef]

(C) 2017 by the authors. Licensee MDPI, Basel, Switzerland. This article is an open access article distributed under the terms and conditions of the Creative Commons Attribution (CC BY) license (http:/ / creativecommons.org/licenses/by/4.0/). 